\title{
Serum Carotenoids Reveal Poor Fruit and Vegetable Intake among Schoolchildren in Burkina Faso
}

\author{
Jean Fidèle Bationo ${ }^{1}$, Augustin N. Zeba ${ }^{2}$, Souheila Abbeddou ${ }^{3}$, Nadine D. Coulibaly ${ }^{2}$, \\ Olivier O. Sombier ${ }^{2}$, Jesse Sheftel ${ }^{4}\left(\mathbb{D}\right.$, Imael Henri Nestor Bassole ${ }^{5}$, Nicolas Barro ${ }^{5}$, \\ Jean Bosco Ouedraogo ${ }^{2}$ and Sherry A. Tanumihardjo ${ }^{4, *}$ \\ 1 Centre Muraz, Post Office Box 390, Bobo Dioulasso 01, Burkina Faso; jeanfidelebationo@gmail.com \\ 2 Institute de Recherche en Sciences de la Santé, Post Office Box 545, Bobo Dioulasso 01, Burkina Faso; \\ nawidzeba@gmail.com (A.N.Z.); nadineyd@yahoo.fr (N.D.C.); sombieolivier@yahoo.fr (O.O.S.); \\ jbouedraogo@gmail.com (J.B.O.) \\ 3 University of Ghent, Department Public Health; 9000 Ghent, Belgium; Souheila.Abbeddou@ugent.be \\ 4 University of Wisconsin-Madison, Nutritional Sciences Department; Madison, WI 53706, USA; \\ jsheftel@wisc.edu \\ 5 Université Ouaga 1 Joseph Ki-Zerbo, Ouagadougou 03, Burkina Faso; ismael.bassole@gmail.com (I.H.N.B.); \\ barronicolas@yahoo.fr (N.B.) \\ * Correspondence: sherry@nutrisci.wisc.edu
}

Received: 27 August 2018; Accepted: 27 September 2018; Published: 4 October 2018

\begin{abstract}
The health benefits of fruits and vegetables are well-documented. Those rich in provitamin A carotenoids are good sources of vitamin A. This cross-sectional study indirectly assessed fruit and vegetable intakes using serum carotenoids in 193 schoolchildren aged 7 to 12 years in the Western part of Burkina Faso. The mean total serum carotenoid concentration was $0.23 \pm 0.29 \mu \mathrm{mol} / \mathrm{L}$, which included $\alpha$ - and $\beta$-carotene, lutein, and $\beta$-cryptoxanthin, and determined with serum retinol concentrations in a single analysis with high performance liquid chromatography. Serum retinol concentration was $0.80 \pm 0.35 \mu \mathrm{mol} / \mathrm{L}$ with $46 \%$ of children $(n=88)$ having low values $<0.7 \mu \mathrm{mol} / \mathrm{L}$. Total serum carotene (the sum of $\alpha$ - and $\beta$-carotene) concentration was $0.13 \pm 0.24 \mu \mathrm{mol} / \mathrm{L}$, well below the reference range of $0.9-3.7 \mu \mathrm{mol}$ carotene/L used to assess habitual intake of fruits and vegetables. Individual carotenoid concentrations were determined for $\alpha$-carotene $(0.01 \pm 0.05 \mu \mathrm{mol} / \mathrm{L}), \beta$-carotene $(0.17 \pm 0.24 \mu \mathrm{mol} / \mathrm{L}), \beta$-cryptoxanthin $(0.07 \pm 0.06 \mu \mathrm{mol} / \mathrm{L})$, and lutein $(0.06 \pm 0.05 \mu \mathrm{mol} / \mathrm{L})$. These results confirm the previously measured high prevalence of low serum vitamin A concentrations and adds information about low serum carotenoids among schoolchildren suggesting that they have low intakes of provitamin A-rich fruits and vegetables.
\end{abstract}

Keywords: $\alpha$-carotene; $\beta$-carotene; $\beta$-cryptoxanthin; carotenoids; lutein; provitamin A; retinol; vitamin A

\section{Introduction}

Micronutrient deficiencies among children under 5 years old in low- and middle-income countries are common. Iron, vitamin A (VA), and zinc are specifically targeted for improvement by the World Health Organization (WHO) because their deficiencies are prevalent and lead to increased mortality and morbidity [1]. Community randomized controlled trials have shown that administering preformed VA solely or in combination with zinc to children in regions with a high prevalence of malaria, reduced morbidity [2,3]. Targeting preschool children is of specific interest because of long-term detrimental effects of undernutrition on cognitive development and adulthood work productivity [1]. VA deficiency (VAD) can lead to anemia, stunting, weakened resistance to infection, blindness, and death [1]. A random-effects meta-analysis of several VA trials showed reduction of mortality rates by $24 \%$ among children $6-59$ months 
of age [4]. Current strategies to alleviate VAD are targeted high-dose VA supplementation to 6-59 months old children, fortification of foods that have high population coverage with preformed VA as retinyl palmitate and promoting the consumption of foods rich in VA and provitamin A carotenoids [1,5-7].

Despite a biannual campaign distributing high-dose VA capsules to children $<59$ months, VAD remains a public health problem in Burkina Faso [8]. Schoolchildren are assumed to be at lower risk but likely also suffer from micronutrient deficiencies in areas with low dietary diversity. Worldwide, 190 million preschool children are estimated to have VAD [1]. In Kaya ( $n=214$, age $8.5 \pm 1.6$ years) and Bogandé ( $n=337$, age $6.2-10.3$ years), Burkina Faso, $47.2 \%$ and $37.1 \%$ of schoolchildren, respectively, had low serum retinol concentrations [9]. In Ouagadougou, 38.7\% of 7-14 years old children attending private or public school had low serum retinol, which was more prevalent among children in public schools [10]. Low serum retinol concentration is an indicator of VAD and is currently recommended by WHO when used along with other biomarkers or surveys [11]. A prevalence of $20 \%$ of a given population group with serum retinol concentrations $<0.7 \mu \mathrm{mol} / \mathrm{L}$, is used to define VAD as a severe public health problem [11].

Micronutrient deficiencies in schoolchildren represent an additional concern because of increased nutritional needs for development, health, and academic performance [12]; this period can be as important as early infancy due to catch-up growth. In low- and middle-income countries where intake of animal-based foods is low, dietary provitamin A carotenoids are the main source of VA [13]. Due to economic reasons, limited knowledge and restricted access, the frequency and quantity of fruits and vegetables consumed by Burkinabe children is inadequate [7]. Increased access by children allowing repeat exposure showed an association with enhanced taste preferences towards increased fruit and vegetable intake [14]. Green leafy vegetables, orange fruits, and yellow-colored vegetables are rich in carotenoids and important for optimal health [13], and serum carotenoid concentrations reflect consumption of these fruits and vegetables $[15,16]$. The present study assessed serum retinol and carotenoid concentrations among schoolchildren (aged 7-12 years) in Burkina Faso to compare carotenoid-containing fruit and vegetable intake with other countries to determine relative consumption.

\section{Materials and Methods}

\subsection{Study Area and Subjects}

This study was conducted according to the guidelines laid down in the Declaration of Helsinki and all procedures involving human subjects/patients were approved by the Ethical Review Committee of Center MURAZ (001-2014/CE-CM). Written informed consent was obtained from parents or guardians of all included subjects. The trial was registered at Pan African Clinical Trials Registry (PACTR201702001947398). This cross-sectional study was conducted in the Western part of Burkina Faso, in primary school "A" of Kou's Valley in Bama's village in the Dande health district, between March and April 2014 during the dry season. Children attending the school were considered eligible if they were 7-12 years old living in the area; and their caregiver signed an informed consent form.

Exclusion criteria included clinical VAD, i.e., physiological ocular symptoms; severe anemia defined as hemoglobin $(\mathrm{Hb})$ concentration $<70 \mathrm{~g} / \mathrm{L}$ [17]; serious illness (based on a medical examination) including tuberculosis and symptomatic human immunodeficiency virus infection. Children were enrolled based on the list of classes as a sampling frame. Recruitment covered the first four years of school (preparatory and elementary levels). We used $z$-score to assess anthropometric parameters based on WHO growth standards. Underweight was defined as WAZ more than 2 standard deviations (SDs) below the WHO median [18].

\subsection{Data and Sample Collection}

Venous blood $(7 \mathrm{~mL})$ was collected in EDTA tubes by trained nurses of Bama's clinic and stored immediately on ice before transportation to the laboratories of the Institut de Recherche en Sciences de la Santé (IRSS, Bobo-Dioulasso). Vials were protected from light with aluminum foil to avoid photo-degradation of the carotenoids and retinol. Blood samples were centrifuged the same day at 
3000 rpm for 10-min with a Universal 320R centrifuge (Hettich Zentrifugen, D-78532, Tuttlingen, Germany). Serum was transferred into brown $1.5 \mathrm{~mL}$ microcentrifuge tubes (Eppendorf, Hamburg, Germany) and stored at $-20{ }^{\circ} \mathrm{C}$ until shipment to the University of Wisconsin-Madison, USA (UW) for serum retinol and carotenoid analyses. Malaria parasites were counted on thick blood smears prepared in the field from capillary blood. $\mathrm{Hb}$ concentration was measured on capillary blood with the 301+ Hemocue system (Angelholm, Sweden). Height to the nearest $0.1 \mathrm{~cm}$ and weight to the nearest $10 \mathrm{~g}$ were measured.

\subsection{Serum Retinol and Carotenoid Extraction and Analys}

Serum retinol and carotenoid analyses were performed at UW in the same analysis as described $[15,16]$ with modifications. To $200-300 \mu \mathrm{L}$ serum, ethanol $(1.5 \mathrm{X} \mathrm{v})$ containing $0.1 \%$ butylated hydroxytoluene (MP Biomedicals, Solon, OH, USA) as an antioxidant, and $25 \mu \mathrm{L}$ C23- $\beta$-apo-carotenol as an internal standard were added followed by 3 extractions with hexanes $(2.5 \mathrm{X} v)$ (Fisher Scientific, Pittsburgh, PA, USA). Pooled hexanes were dried under nitrogen and reconstituted in $100 \mu \mathrm{L}$ 50:50 (v/v) methanol:dichloroethane; $50 \mu \mathrm{L}$ was injected into a Waters HPLC [16] equipped with a Sunfire C18 (5 $\mathrm{m}, 4.6 \times 250 \mathrm{~mm}$ ) analytic column (Waters, Inc., Milford, MA, USA) and a guard column. Samples were run at $1 \mathrm{~mL} / \mathrm{min}$ using 70:30 (v/v) methanol:water (solvent A) and 80:20 (v/v) methanol:dichloroethane (solvent B), both with $10 \mathrm{mM}$ ammonium acetate as a modifier, with the following gradient: 10-min linear gradient from 50\% A:50\% B to 100\% B, followed by a 20-min hold, 3-min linear gradient to 50\% A:50\% B, and 6-min equilibration. Chromatograms were evaluated at $450 \mathrm{~nm}$ for carotenoids and $325 \mathrm{~nm}$ for retinol using purified external standards.

\subsection{Statistical Methods}

All analyses were conducted using the Statistical Analysis System (version 9.4; SAS Institute, Cary, NC, USA). Descriptive statistics were used to summarize nutritional characteristics of the participants as well as the main outcomes. $z$-scores were determined using WHO Anthro. The difference between Body Mass Index (BMI)-for-age $z$-scores of the children and WHO standards $(z$-score $=0)$ was analyzed by one-sample Student's $t$-test. Data were reported as mean $\pm \mathrm{SD}$.

\section{Results}

\subsection{Subject Characteristics}

All children $(n=193)$ met inclusion criteria and none of them had ocular signs of VAD, had blood samples drawn, and had anthropometric parameters measured (Table 1). Comparing BMI-for-age $z$-score (BAZ) of the children to WHO growth standards determined that mean BAZ was $-1.24 \pm 1.05$ (different from $0, p<0.0001$ ) with 20\% (CI =95\%) low BAZ (Figure 1). The children had high prevalence of underweight $(17.6 \%$ with $\mathrm{CI}=95 \%)$, stunting $(25.2 \%$ with $\mathrm{CI}=95 \%)$, asymptomatic malaria $(39.5 \%)$, and prevalent anemia ( $23 \%$ with $\mathrm{Hb}$ concentration $<110 \mathrm{~g} / \mathrm{L})$.

Table 1. Subject characteristics.

\begin{tabular}{cc}
\hline Parameter & Value (mean \pm SD) \\
\hline Age, year & $9.3 \pm 1.48$ \\
Height, cm & $129.1 \pm 12.4$ \\
Weight, kg & $24.8 \pm 5.37$ \\
Height-for-age z-score & $-0.73 \pm 1.25$ \\
Weight-for-age z-score & $-1.16 \pm 1.01$ \\
BMI-for-age z-score & $-1.24 \pm 1.05$ \\
Hemoglobin, g/L & $122.4 \pm 10.9$ \\
Positive malaria blood smear, \% (average parasitemia) & $39.5(1655$ parasites) \\
\hline
\end{tabular}




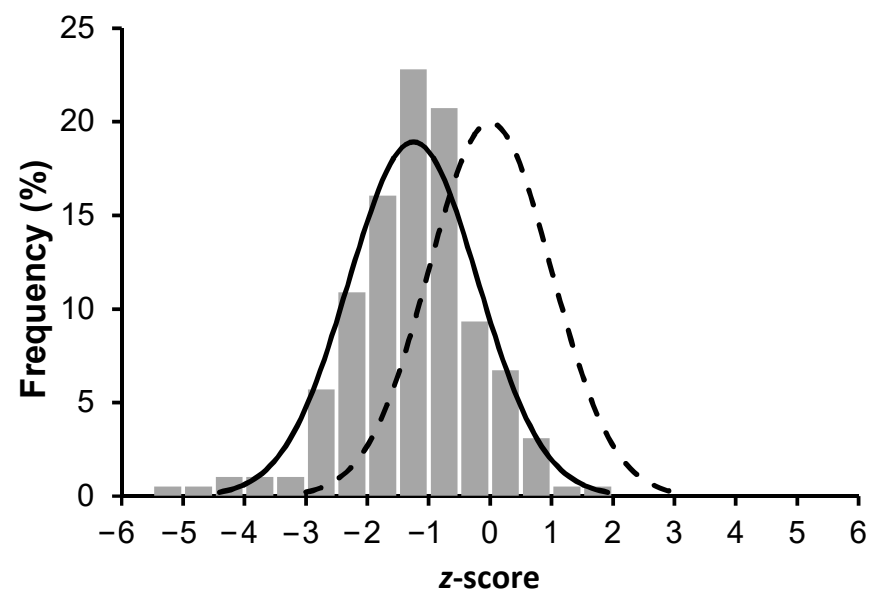

Figure 1. BMI-for-age $z$-score distribution in children aged $7-12$ years $(n=193)$ in Burkina Faso. The normal distribution curves are given for these children (solid line, mean $=-1.24 \pm 1.05$ ) compared with the WHO child growth standards for children 61 months-19 years of age (dashed line, mean $=0 \pm 1$ ).

\subsection{Serum Retinol and Carotenoid Concentrations}

Mean serum retinol concentration was $0.80 \pm 0.35 \mu \mathrm{mol} / \mathrm{L}$ with $46 \%$ (88 children out of 193 ) $<0.7 \mu \mathrm{mol} / \mathrm{L}$ (the cut-off for VAD) [11], although the utility of this measurement is limited as markers of chronic or acute inflammation (e.g., $\alpha_{1}$-acid glycoprotein and C-reactive protein) were not taken to correct for the impact of infection in these children, which is known to lower serum retinol independent of VA status [11]. Concentrations of lutein, $\alpha$ - and $\beta$-carotene, and $\beta$-cryptoxanthin were determined and compared with other studies in children (Table 2). Total serum carotenoids ranged from 0 to $2.82 \mu \mathrm{mol} / \mathrm{L}$ with a mean of $0.23 \pm 0.29 \mu \mathrm{mol} / \mathrm{L}$. Serum carotenes had a low mean concentration $(0.13 \pm 0.24 \mu \mathrm{mol} / \mathrm{L})$ well under the reference range $(0.9-3.7 \mu \mathrm{mol} / \mathrm{L})[16]$, and only two children were within this reference range. Serum retinol concentrations were not related to serum provitamin A carotenoid concentrations $p>0.05$ ).

Table 2. Serum carotenoids concentrations $( \pm S D)$ or range in apparently healthy children from various regions of the world.

\begin{tabular}{|c|c|c|c|c|c|c|c|c|}
\hline Country & $\begin{array}{l}\text { Age } \\
\text { Years }\end{array}$ & $n$ & $\begin{array}{l}\text { Retinol } \\
\mu \mathrm{mol} / \mathrm{L}\end{array}$ & $\begin{array}{c}\beta \text {-Carotene } \\
\mu \mathrm{mol} / \mathrm{L}\end{array}$ & $\begin{array}{c}\alpha \text {-Carotene } \\
\mu \mathrm{mol} / \mathrm{L}\end{array}$ & $\begin{array}{c}\beta \text {-Cryptoxanthin } \\
\mu \mathrm{mol} / \mathrm{L}\end{array}$ & $\begin{array}{l}\text { Lutein } \\
\mu \mathrm{mol} / \mathrm{L}\end{array}$ & Reference \\
\hline $\begin{array}{l}\text { Burkina Faso } \\
\text { (range) }\end{array}$ & $7-12$ & 193 & $\begin{array}{l}0.80 \pm 0.35 \\
(0.17-1.92)\end{array}$ & $\begin{array}{l}0.12 \pm 0.21 \\
(0.004-2.15)\end{array}$ & $\begin{array}{l}0.01 \pm 0.04 \\
\quad(0-0.4)\end{array}$ & $\begin{array}{c}0.05 \pm 0.06 \\
(0-0.3)\end{array}$ & $\begin{array}{c}0.05 \pm 0.06 \\
(0-0.2)\end{array}$ & Present study \\
\hline Zambia & $5-7$ & 123 & 0.98 & 0.76 & 0.62 & 0.10 & 0.86 & Mondloch et al. [16] \\
\hline Senegal & $2-4$ & 281 & - & 0.16 & 0.030 & 0.020 & 0.46 & Rankins et al. [19] \\
\hline India & $2-11$ & 50 & 1.10 & 0.31 & 0.035 & 0.12 & 0.42 & Das et al. [20] \\
\hline Philippines & $9-12$ & 27 & 0.87 & 0.23 & 0.03 & 0.07 & 0.23 & Ribaya-Mercado et al. [21] \\
\hline USA & $6-7$ & 839 & - & 0.34 & 0.075 & 0.21 & $0.34^{\mathrm{a}}$ & Ford et al. [22] \\
\hline
\end{tabular}

a This value includes the xanthophyll zeaxanthin.

\section{Discussion}

The high prevalence of low serum retinol concentrations is consistent with research in other regions from Burkina Faso $[9,10]$. One-quarter of the children were anemic, with almost $40 \%$ of those presenting with asymptomatic malaria. Serum concentrations of the four measured carotenoids were lower than those found in other populations, including young preschool children and schoolchildren from other low-income countries (Table 2) [16,19-22]. Low fruit and vegetable consumption has been recognized as a key contributor to inadequate micronutrient intake and deficiencies affecting optimal health [13]. Intake of provitamin A-source foods was likely quite low as demonstrated by low serum retinol and carotenoid concentrations. Previous studies in Bolivia, Burkina Faso, and the Philippines showed that the diets are mainly based on cereals and tubers with white flesh and poor in carotenoids [23,24]. 
Staple foods are traditionally consumed with vegetable sauces in Burkina Faso, which could be good carotenoid sources, but data from previous studies showed high intake of vegetables that are poor in carotenoids, such as dried okra. The Institute of Medicine has defined bioefficacy of dietary $\beta$-carotene, $\alpha$-carotene, and $\beta$-cryptoxanthin as 12,24 , and $24 \mu \mathrm{g}$ to $1 \mu \mathrm{g}$ retinol activity equivalents (RAE), respectively [25]. Dried okra, which has $<5 \mu \mathrm{g}$ RAE/100 g [26], is reportedly consumed daily in rural areas of Burkina Faso [24]. On the other hand, sorrel (Rumex acetosa L., a small green herb), which contains 75-140 $\mu \mathrm{g}$ RAE/100 g [26,27], is reportedly consumed in only one meal in six days (generally market day) [26,27] while Weber and Grune showed that carotenoids make up 35\% of total VA intake in industrialized countries [28].

Dietary data collected previously showed that intake of fruits and vegetables is generally poor, due to low frequency and small quantities [26,27]. An intervention was able to increase intake of sorrel leaves and provide an extra 35-49 $\mu \mathrm{g}$ RAE to schoolchildren (Table 3) [27]. A previous 4-month trial in Burkina Faso showed that red palm oil (RPO), naturally rich in carotenoids, can cover daily VA needs for children $<6$ years of age [10]. Rural populations cannot afford refined VA-fortified oil, so promotion of RPO may be appropriate and add VA-value to vegetables poor in RAE, such as okra $[26,27]$. Although, the study village produced agricultural products, dietary habits, and cultural restrictions limited food diversification. Most people do not consume papaya for cultural reasons [26]. Other fruits and vegetables constitute an income for mothers who sell the products instead of using them for household consumption [26].

Table 3. Retinol activity equivalents (RAE) from sauce intake in Burkinabe children and coverage of the child's vitamin A requirements in relationship to the Estimated Average Requirements and the Recommended Daily Allowances.

\begin{tabular}{|c|c|c|c|c|}
\hline $\begin{array}{c}\text { Characteristic } \\
\text { Age group }\end{array}$ & \multicolumn{2}{|c|}{ Normal Diet ${ }^{\text {a }}$} & \multicolumn{2}{|c|}{ Added Green Leafy Vegetables } \\
\hline Number of meals/day & 2 & 2 & 2 & 2 \\
\hline Amount of sauce ingested/day (g) & 184 & 254 & 184 & 254 \\
\hline Mean retinol activity equivalents ( $\mu \mathrm{g}$ RAE/100 g) & 36 & 36 & 55 & 55 \\
\hline Mean intakes of retinol activity ( $\mu \mathrm{g}$ RAE/day) & 66 & 91 & 101 & 140 \\
\hline \multicolumn{5}{|l|}{ Estimated average requirements [25] ( $\mu \mathrm{g}$ RAE/day) } \\
\hline Boys (6-13 years) & $275-445$ & 445 & $275-445$ & 445 \\
\hline Recommended Daily Allowance [25] (g RAE/day) & $400-600$ & 600 & $400-600$ & 600 \\
\hline $\begin{array}{l}\% \text { of estimated average requirements met/day for boys and girls } \\
\text { aged 6-13 years }\end{array}$ & $15-24$ & $20-22$ & $23-37$ & $31-33$ \\
\hline
\end{tabular}

Data based on information in reference [26]; RAE, Retinol Activity Equivalent. ${ }^{\text {a }}$ The normal diet included 60 households in a rural area of Burkina Faso that received no intervention. ${ }^{b}$ Green leafy vegetables were provided to 30 households from the same area that received locally-produced sorrel leaves at intervals corresponding to market day frequencies (every 3 days) for two months.

Serum carotenoid concentrations are influenced by bioavailability and overall bioefficacy $[13,25]$. Bioconversion of provitamin A carotenoids to retinol is affected by VA status and host-related facts, such as genetic polymorphisms [25]. Because different bioefficacy factors are used for provitamin A carotenoids, food composition data tables should report food VA content in mass of each carotenoid whenever possible [13]. We recognize some shortcomings of the study. The lack of dietary data on intake of fruits, vegetables, and other sources of VA and carotenoids is an important limitation of our study. Furthermore, biomarkers of inflammation like C-reactive protein and $\alpha_{1}$-acid glycoprotein, which impact serum retinol, were not measured [11]. Malaria in Burkina Faso is endemic, which has been associated with low serum retinol concentrations in Thailand [29]. Serum retinol also suffers from sensitivity and specificity issues [11]. Determination of confounding factors and the causes of low serum retinol concentrations in this community would allow us to form more concrete associations among variables.

This study biochemically suggested poor fruit and vegetable intake among schoolchildren in Burkina Faso and demonstrated that low serum retinol concentrations are still prevalent, adding to the body of evidence that large-scale promotion of naturally rich RPO or food fortification may be needed 
among the population. Vegetable intervention studies should be pursued to evaluate whether locally available vegetables could be efficacious. Additionally, it shows the importance of behavior change education to increase dietary diversity. Dietary validation studies of self-reported fruit and vegetable intake should ideally include measurement of serum biomarkers of intake. Fruits and vegetables should be available and accessible both at home and at school. To date, there are a limited number of studies evaluating school-based environments to increase availability and accessibility of fruits and vegetables for children.

Author Contributions: Writing—original draft preparation, J.F.B., S.A. and J.S.; conceptualization, A.N.Z., J.B.O. and S.A.T.; methodology, J.F.B. and J.S.; validation, S.A. and S.A.T.; investigation, J.F.B., A.N.Z., N.D.C. and O.O.S.; academic oversight for J.F.B., I.H.N.B. and N.B.; resources, J.B.O. and S.A.T.; data curation, J.F.B. and J.S.; writing-review and editing, S.A., J.S. and S.A.T.; supervision, A.N.Z., J.B.O. and S.A.T.; project administration, A.N.Z. and J.B.O.; funding acquisition, A.N.Z., J.B.O. and S.A.T.

Funding: This work was supported by the International Atomic Energy Agency and Global Health funds at UW-Madison during sample analysis and manuscript preparation.

Conflicts of Interest: The authors declare no conflict of interest. The funders had no role in the design of the study; in the collection, analyses, or interpretation of data; in the writing of the manuscript, and in the decision to publish the results.

\section{References}

1. Essential Nutrition Actions: Improving Maternal, Newborn, Infant and Young Child Health and Nutrition; World Health Organization: Geneva, Switzerland, 2013.

2. Zeba, A.N.; Sorgho, H.; Rouamba, N.; Zongo, I.; Rouamba, J.; Guiguemdë, R.T.; Hamer, D.H.; Mokhtar, N.; Ouedraogo, J.B. Major reduction of malaria morbidity with combined vitamin A and zinc supplementation in young children in Burkina Faso: A randomized double blind trial. Nutr. J. 2008, 7, 7. [CrossRef] [PubMed]

3. Shankar, A.H.; Genton, B.; Semba, R.D.; Baisor, M.; Paino, J.; Tamja, S.; Adiguma, T.; Wu, L.; Rare, L.; Tielsch, J.M.; et al. Effect of vitamin A supplementation on morbidity due to Plasmodium falciparum in young children in Papua New Guinea: A randomised trial. Lancet 1999, 354, 203-209. [CrossRef]

4. Imdad, A.; Mayo-Wilson, E.; Herzer, K.; Bhutta, Z.A. Vitamin A supplementation for preventing morbidity and mortality in children from six months to five years of age. Cochrane Database Syst. Rev. 2017, 3, CD008524. [CrossRef] [PubMed]

5. Krause, V.M.; Delisle, H.; Solomons, N.W. Fortified foods contribute one half of recommended vitamin A intake in poor urban Guatemalan toddlers. J. Nutr. 1998, 128, 860-864. [CrossRef] [PubMed]

6. Engle-Stone, R.; Nankap, M.; Ndjebayi, A.O.; Brown, K.H. Simulations based on representative 24-h recall data predict region-specific differences in adequacy of vitamin A intake among Cameroonian women and young children following large-scale fortification of vegetable oil and other potential food vehicles. J. Nutr. 2014, 144, 1826-1834. [CrossRef] [PubMed]

7. Nana, C.P.; Brouwer, I.D.; Zagré, N.M.; Kok, F.J.; Traoré, A.S. Impact of promotion of mango and liver as sources of vitamin A for young children: A pilot study in Burkina Faso. Public Health Nutr. 2016, 9, 808-813. [CrossRef]

8. Plan National d'Action Pour La Nutrition, Version Révisée; Ministère de la Santé: Ouagadougou, Burkina Faso, 2001.

9. Daboné, C.; Delisle, H.F.; Receveur, O. Poor nutritional status of schoolchildren in urban and peri-urban areas of Ouagadougou (Burkina Faso). Nutr. J. 2011, 10, 34. [CrossRef] [PubMed]

10. Zeba, A.N.; Prével, Y.M.; Somé, I.T.; Delisle, H.F. The positive impact of red palm oil in school meals on vitamin A status: Study in Burkina Faso. Nutr. J. 2006, 5, 17. [CrossRef] [PubMed]

11. Tanumihardjo, S.A.; Russell, R.M.; Stephensen, C.B.; Gannon, B.M.; Craft, N.E.; Haskell, M.J.; Lietz, G.; Schulze, K.; Raiten, D.J. Biomarkers of nutrition for development (BOND)-Vitamin A review. J. Nutr. 2016, 146, 1816S-1848S. [CrossRef] [PubMed]

12. Schoenthaler, S.J.; Bier, I.D.; Young, K.; Nichols, D.; Jansenns, S. The effect of vitamin-mineral supplementation on the intelligence of American schoolchildren: A randomized, double-blind placebo-controlled trial. J. Altern. Complement. Med. 2000, 6, 19-29. [CrossRef] [PubMed]

13. Tanumhardjo, S.A.; Palacios, N.; Pixley, K.V. Provitamin A carotenoid bioavailability: What really matters? Int. J. Vitam. Nutr. Res. 2010, 80, 336-350. [CrossRef] [PubMed] 
14. Blanchette, L.; Brugg, J. Determinants of fruit and vegetable consumption among 6-12-year-old children and effective interventions to increase consumption. J. Hum. Nutr. Diet. 2005, 18, 431-443. [CrossRef] [PubMed]

15. Yang, Z.; Zhang, Z.; Penniston, K.L.; Binkley, N.; Tanumihardjo, S.A. Serum carotenoid concentrations in postmenopausal women from the United States with and without osteoporosis. Int. J. Vit. Nutr. Res. 2008, 78, 105-111. [CrossRef] [PubMed]

16. Mondloch, S.; Gannon, B.M.; Davis, C.R.; Chileshe, J.; Kaliwile, C.; Masi, C.; Rios-Avila, L.; Gregory, J.F., 3rd; Tanumihardjo, S.A. High provitamin A carotenoid serum concentrations, elevated retinyl esters, and saturated retinol-binding protein in Zambian preschool children are consistent with the presence of high liver vitamin A stores. Am. J. Clin. Nutr. 2015, 102, 497-504. [CrossRef] [PubMed]

17. Vitamin and Mineral Nutrition Information System-Haemoglobin Concentrations for the Diagnosis of Anaemia and Assessment of Severity; World Health Organization: Geneva, Switzerland, 2011.

18. Comparison of the World Health Organization (WHO) Child Growth Standards and the National Center for Health Statistics/WHO International Growth Reference: Implications for Child Health Programmes; World Health Organization: Geneva, Switzerland, 2011.

19. Rankins, J.; Green, N.R.; Tremper, W.; Stacewitcz-Sapuntzakis, M.; Bowen, P.; Ndiaye, M. Undernutrition and vitamin A deficiency in the Department of Linguère, Louga Region of Sénégal. Am. J. Clin. Nutr. 1993, 58, 91-97. [CrossRef] [PubMed]

20. Das, B.S.; Thurnham, D.I.; Das, D.B. Plasma $\alpha$-tocopherol, retinol and carotenoids in children with falciparum malaria. Am. J. Clin. Nutr. 1996, 64, 94-100. [CrossRef] [PubMed]

21. Ribaya-Mercado, J.D.; Maramag, C.C.; Tengco, L.W.; Blumberg, J.B.; Solon, F.S. Relationships of body mass index with serum carotenoids, tocopherols and retinol at steady-state and in response to a carotenoid rich vegetable diet intervention in Filipino schoolchildren. Biosci. Rep. 2008, 28, 97-106. [CrossRef] [PubMed]

22. Ford, E.S.; Gillespie, C.; Ballew, C.; Sowell, A.; Mannino, D.M. Serum carotenoid concentrations in US children and adolescents. Am. J. Clin. Nutr. 2002, 76, 818-827. [CrossRef] [PubMed]

23. Melgar-Quinonez, H.R.; Zubieta, A.C.; MkNelly, B.; Nteziyaremye, A.; Gerardo, M.F.; Dunford, C. Household food insecurity and food expenditure in Bolivia, Burkina Faso and the Philippines. J. Nutr. 2006, 136, 1431S-1437S. [CrossRef] [PubMed]

24. Belesova, K.; Gasparrini, A.; Sié, A.; Sauerborn, R.; Wilkinson, P. Household cereal crop harvest and children's nutritional status in rural Burkina Faso. Environ. Health 2017, 16, 65. [CrossRef] [PubMed]

25. Institute of Medicine, Food and Nutrition Board. Dietary Reference Intakes for Vitamin A, Vitamin K, Arsenic, Boron, Chromium, Copper, Iodine, Iron, Manganese, Molybdenum, Nickel, Silicon, Vanadium, and Zinc; National Academy Press: Washington, DC, USA, 2001; pp. 65-126.

26. Nana, C.P.; Brouwer, I.D.; Zagré, N.M.; Kok, F.J.; Traoré, A.S. Community assessment of availability, consumption, and cultural acceptability of food sources of (pro)vitamin A: Toward the development of a dietary intervention among preschool children in rural Burkina Faso. Food Nutr. Bull. 2005, 26, 356-365. [CrossRef] [PubMed]

27. Ayassou, K.; Ouedraogo, M.; Mathieu-Daudé, C.; Alain, B.; Chevalier, P. Amélioration de L'alimentation Burkinabè Avec Des Aliments Riches en Caroténoïdes. Available online: http:/ / horizon.documentation.ird. fr/exl-doc/pleins_textes/divers11-08/010036323.pdf (accessed on 13 July 2018).

28. Weber, D.; Grune, T. The contribution of $\beta$-carotene to vitamin A supply of humans. Mol. Nutr. Food Res. 2012, 56, 251-258. [CrossRef] [PubMed]

29. Stuetz, W.; McGready, R.; Cho, T.; Prapamontol, T.; Biesalski, H.K.; Stepniewska, K.; Nosten, F. Relation of DDT residues to plasma retinol, alpha-tocopherol, and beta-carotene during pregnancy and malaria infection: A case-control study in Karen women in northern Thailand. Sci. Total Environ. 2006, 363, 78-86. [CrossRef] [PubMed]

(C) 2018 by the authors. Licensee MDPI, Basel, Switzerland. This article is an open access article distributed under the terms and conditions of the Creative Commons Attribution (CC BY) license (http://creativecommons.org/licenses/by/4.0/). 